\title{
Jamais esquecer do golpe de 2016
}

\section{Guilherme Ribeiro}

\section{(2) OpenEdition \\ Journals}

Edição electrónica

URL: http://journals.openedition.org/espacoeconomia/2311

DOI: 10.4000/espacoeconomia.2311

ISSN: 2317-7837

\section{Editora}

Núcleo de Pesquisa Espaço \& Economia

\section{Refêrencia eletrónica}

Guilherme Ribeiro, « Jamais esquecer do golpe de 2016 », Espaço e Economia [Online], 8| 2016, posto online no dia 17 outubro 2016, consultado o 24 setembro 2020. URL : http://journals.openedition.org/ espacoeconomia/2311; DOI : https://doi.org/10.4000/espacoeconomia.2311

Este documento foi criado de forma automática no dia 24 setembro 2020.

(c) NUPEE 


\title{
Jamais esquecer do golpe de 2016
}

\author{
Guilherme Ribeiro
}

1 Sinto-me profundamente envergonhado por testemunhar o golpe parlamentar contra a presidenta democraticamente eleita Dilma Rousseff. $O$ ano de 2016 será marcado por um profundo retrocesso na história política brasileira, com atuações repugnantes por parte da classe política e da mídia hegemônica. Esta apoiou o golpe do início ao fim, contribuindo decisivamente para que um governo ilegítimo assaltasse o poder revelando, assim, sua face mais reacionária e perversa. Aquela foi liderada pelo Presidente da Câmara dos Deputados, Eduardo Cunha, réu em inúmeras ações ligadas a desvio de dinheiro, e pelo próprio Vice-Presidente da República, Michel Temer. Todo o processo teve o aval do Supremo Tribunal Federal.

2 Não podemos confundir as coisas. O envolvimento de quadros do Partido dos Trabalhadores como José Dirceu em esquemas corruptos, o financiamento de campanhas deste partido pelas maiores empreiteiras do país e as suspeitas de enriquecimento ilícito do ex-presidente Lula não justificam, em hipótese alguma, o golpe na democracia brasileira perpetrado pelo PMDB e apoiado pelo PSDB e pelos maiores veículos da imprensa nacional.

3 Repita-se mil e uma vezes: o impeachment foi um golpe da direita.

4 Infelizmente, há também que se dizer com todas as letras, parcela significativa da sociedade civil aderiu à farsa sem maiores constrangimentos. Afinal, para ela tratou-se de corrigir o "erro" das urnas em 2014, quando 51,64\% da população optou pela reeleição de Dilma Rousseff e $48,36 \%$ por Aécio Neves.

Do ponto de vista mais amplo, temos pouco apreço por nossas instituições. No mesmo diapasão, o sentido da coisa pública, notadamente frágil, desaparece por completo quando interesses individuais são contrariados. No Brasil, as empresas e as elites alegam têm pavor do Estado, porém dependem umbilicalmente dele para enriquecer ou obter algum tipo de favorecimento. Do outro lado, os que de fato mais precisam do Estado são os que menos se beneficiam dele!

6 Eis a razão pela qual jamais a pauta relativa a saúde, educação, transporte, habitação, reforma agrária e saneamento avançou a contento, pois as classes dirigentes não se cansam de dar as costas para a sociedade. A verdade é que assalariados e camadas 
populares só conhecem o Estado pela força da lei e da violência. Não é por acaso que toda e qualquer manifestação vira caso de polícia.

o fato de o golpista Michel Temer ter feito a primeira viagem internacional à China está longe de ser mera coincidência: sua gestão saturou o país da atmosfera do regime militar. Ameaça-nos um Estado de exceção (AGAMBEN, 2004 [2003] ou já estamos vivendo nele sem vontade nenhuma de admitir? Aliás, o que esperar de uma sociedade autoritária (CHAUÍ, 2000) como a nossa?

8 Quão desgosto é constatar a esquerda brasileira sendo questionada por assalto aos cofres público e falta de ética por gente como Fernando Collor (PTC), Ronaldo Caiado (DEM [antigo PFL]) e Renan Calheiros (PMDB). É esta a direita que levanta a voz e se apresenta como a melhor e mais sensata alternativa para a nação. A que ponto chegamos? A propósito, a Lava Jato só fará valer o alcance pleno da palavra Justiça se voltar suas investigações também para os donos do poder (FAORO, 2000 [1958], 2000a [1958]).

9 A esquerda nacional precisa se reerguer com urgência. Do contrário, o artigo profético de Leandro Konder, escrito antes de o PT assumir o poder (KONDER, 2001), desafortunadamente se concretizará.

\section{BIBLIOGRAFIA}

AGAMBEN, Giorgio. Estado de exceção. Campinas: Boitempo (2014 [2013]).

CHAUÍ, Marilena. Brasil: mito fundador e sociedade autoritária. São Paulo: Perseu Abramo (2000).

FAORO, Raimundo. Os Donos do Poder - vol. I. São Paulo: Globo/Publifolha (2000 [1958]).

FAORO, Raimundo. Os Donos do Poder - vol II. São Paulo: Globo/Publifolha (2000a [1958]).

KONDER, Leandro. O PT e o poder. Jornal do Brasil, dom, 17 de junho (2001).

\section{AUTOR}

\section{GUILHERME RIBEIRO}

Doutor em Geografia pela Universidade Federal Fluminense, com doutorado sandwich pela Universidade de Paris - Sorbonne (Paris IV). Pós-Doutor em Geografia pela Universidade Federal de Minas Gerais. Professor do Programa de Pós-Graduação em Geografia da Universidade Federal Rural do Rio de Janeiro. E-mail: geofilos@msn.com 